\title{
Relationship between the digestive system and emotions: a literature review
}

Edson André Batista ${ }^{1}$; Agnys Cecylia Guaraná Melo²; Jéssica Freires de Melo ${ }^{3}$; Vitoria Aparecida Gomes da Silva ${ }^{4}$; Marta Gabriely de Arruda Ribeiro5; Marcio Martins da Silva ${ }^{6}$; Camila Dayanne de Melo Moura ${ }^{7}$; Ludmylla Pereira da Silva ${ }^{8}$; Ariany Rebeka Salgado da Silva9; Jullyana Carollyna Eretiano Rodrigues de Lima ${ }^{10}$; Brunna Lorenna Souza de Lira ${ }^{11}$; Lenislâne da Silva Santos ${ }^{12}$; Mateus Felipe da Silva Bezerra ${ }^{13}$; Teresa Amélia Barros de Souza ${ }^{14}$; Emanuella Barros de Souza Oliveira Álvares ${ }^{15}$; Allyson Rodrigo de Oliveira Lopes*16

01 - 13 Undergraduate Nursing students at Academic Center of Vitória de Santo Antão - UNIVISA
14 - 15 Professor of the Biomedicine course at the University Center of Vitória de Santo Antão - UNIVISA

E-mail adresses: emanuelabarros@univisa.edu.br (Emanuella Barros de Souza Oliveira Álvares), allysonlopes85@gmail.com (Allyson Rodrigo de Oliveira Lopes)

${ }^{*}$ Corresponding author

\section{To cite this article:}

Batista, E.A.; Melo, A.C.G.; Melo, J.F.; Silva, V.A.G.; Ribeiro, M.G.A.; Silva, M.M.; Moura, C.D.M.; Silva, L.P.; Silva, A.R.S.; Lima, J.C.E.R.; Lira, B.L.S.; Santos, L.S.; Bezerra, M.F.S.; Souza, M.I.P.; Souza, T.A.B.; Álvares, E.B.S.O; Lopes, A.R.O. Relationship between the digestive system and emotions: a literature review. International Journal of Sciences. Vol. 2, No. 1, 2021, pp. 34-36. ISSN $2763-5392$.

Received: 06 29, 2021; Accepted: 06 30, 2021; Published: 07 15, 2021

\begin{abstract}
It is known that emotions are part of the human being, directly influencing the immune system and in today's society stress is considered as one of the biggest problems in people's lives. Communication of the brain-intestine-microbiota axis may have altered functions for several reasons, including a change in the intestinal microbiota. This article aims to discuss the relationship between the digestive system and emotions. This is an integrative review of the literature. Stress induces changes in the microbiota, such as the predominance of a bacterium over other phylum's, which may affect the behavior of the brain, inducing the release of inflammatory cytokines that damage the brain neurochemical, leaving the individual more susceptible to anxiety and depression, which may clarify the association between inflammatory bowel disease and mental disorders. It is evident that there is a relationship between the digestive system and emotions, as well as with the normal microbiota and the immune system, through the gut-brain-microbiota axis.
\end{abstract}

]

Keywords: Emotions; Digestive System.

\section{Introduction}

Currently the running life of most people, has raised the level of stress, which is a psychosocial phenomenon that has gained prominence since the 1930s (AGUIAR et al, 2017). Stress causes homeostatic imbalance of the organism, causing changes in the functioning of systems and generating a series of psychosomatic symptoms and signs, including gastritis and other problems in the gastrointestinal tract (SILVA et al, 2016).

It is known that emotions are part of the human being, directly influencing the immune system and in today's society stress is considered one of the biggest problems in people's lives (BATISTA, 2019). Lack of control over emotions affects the microbiota of the human body.

The communication of the brain-intestine-microbiota axis may have altered functions for several reasons, including a change in the intestinal microbiota (JIANG et al, 2015). Intestinal dysbiosis, caused by changes in the axis, presents correlations with diseases such as depression, anxiety and Alzheimer's (YARANDI et al, 2016).

The link between the intestinal microbiota and the central nervous system is seen as renewal of neuroscience patterns (KELLY et al, 2016). Neural projections of the enteric nervous system exert importance in gastrointestinal regulation, influencing gastrointestinal motility and secretion, barrier, besides functioning as a regulatory arm against inflammations in the mucosa (DEJONGE, 2013). Stress-related disorders are related to neuroimmune pathways dysfunctions, which are one of the media in the brain-gut axis - microbiota (KELLY et al, 2016).

In the literature, there are studies that associate the gut 
and brain with cases of depression and anxiety. Because of the sharing of nerve endings and synapse communication, still in the embryonic phase, the brain and intestine maintain narrowing (OZAN, TANIK \& INAN, 2019). Therefore, the functions influence each other, as well as any intestinal disorder, may cause mental disorder (DEL'ARCO, MAGALHÃES \& QUILICI, 2017).

This article aims to discuss the relationship between the digestive system and emotions, through a literature review, focusing on studies on the gut-brain axis.

\section{Methodology}

This is an integrative review of the literature, a means of researching articles on the relationship between the digestive system and the nervous system. For the survey of articles in the literature, a search was conducted in the followingdatabases: Virtual Health Library (VHL),PubMed and Scientific Electronic Library Online (Scielo). Articles, monographs and journals from 2005-2020 and in the years 2020 and in Portuguese. Exclusion criteria were clinical cases and opinions.

\section{Results and Discussion}

Over the years, emotions have been the subject of numerous researches, and the fact that there are increasingly pathologies associated with the emotional aspect, there needs to be an analysis and understanding of the importance of this.

The events of life create affections and effects within the subject. Every conflict needs a transit in the psyche, hence the importance of being able to talk about past experiences that have caused suffering (BOMBANA, 2006). However, it is necessary to take into account that the psychosomatic patient has deficiencies with regard to psychic elaboration and failure in the process of symbolization (DEASSIS et al,2013).

Batista, 2019, points out that any emotional mediation in the digestive system can cause colic, diarrhea, gastritis, ulcer and even irritable bowel syndrome. Araújo and Moreno,2005, mention that gastritis is one of the diseases of inflammatory origin most common to the digestive system, presenting as a characteristic the attack on the gastric mucosa.

Woyciekoski and Hutz, 2009, found that the signs of stress are more noticeable when the individual better understands the combination of emotions, and may even present psychological symptoms. According to Bardini,2020, numerous beneficial situations during stress can be observed when the individual has the ability to shape affective responses in accordance with the environment and the desired objectives.

According to Campos and Rodrigues, 2005, situations that need more attention, in people with difficulty in controlling emotions, generate internal conflicts causing dissatisfaction and suffering.

Rocha et a1., 2013, corroborate with Campos and Rodrigues, 2005, when they affirm that situations where the individual is tested or required of greater effort and attention, such as wars, an important presentation, evidence, among others, can trigger changes in the functioning of the gastrointestinal tract and cause functional diarrhea, especially in children and people suffering from anxiety. Stress caused by such situations is primarily responsible for the emergence of gastritis, mainly for ischemia of the gastric mucosa.

According to De Jonge, 2013, there is direct communication also between immune system cells, especially $\mathrm{T}$ and $\mathrm{B}$ cells, with sympathetic nerve endings. Bravo et al, 2012, suggests that inflammatory bowel diseases, caused by functional disorders, cause the dysregulation of the intestinebrain axis, generating cases of depression linked to stress.

De Jonge, 2013, found that stress induces changes in the microbiota, such as the predominance of a bacterium over the other phylum's, which can affect the behavior of the brain, inducing the release of inflammatory cytokines that damage the brain neurochemical, leaving the individual more susceptible to anxiety and depression, which may clarify the association between inflammatory bowel disease and mental disorders.

According to Lyte, 2011, neurotransmitters such as serotonin that is related to sleep regulation, behavior and bowel movements, among others, can be released by bacteria, such as secondary metabolites. Borre et al, 2014, found that gastrointestinal pathologies and brain changes are associated with tryptophan imbalance, which is a precursor of serotonin.

Kelly et al, 2016, cites a future expectation in the intervention of clinically depressed patients with the use of psychobiotics, due to their positive effect on mood and anxiety in healthy individuals, which may provide a new and beneficial therapeutic approach to neuropathological disorders.

\section{Conclusions}

Emotions can affect the digestive system, as emotional problems lead to various types of physical diseases. It is evident that there is a relationship between the digestive system and emotions, as well as with the normal microbiota and the immune system, through the gut-brain-microbiota axis. In view of this, there is a new perspective on the possibility of having treatment of depression or other mental disorders as well as intestinal disorders from the modulation of the intestine-brain-microbiota axis.

\section{References}

[1] AGUIAR, C. V. N. et al. Cultura organizacional e adoecimento no trabalho: uma revisão sobre as relações entre cultura, burnout e estresse ocupacional. Revista Psicologia, Diversidade e Saúde, v. 6, n. 2, p. 121-131, 2017.

[2] ARAÚJO, C. A.; MORENO, M. T. N. Emoções de raiva associadas à gastrite e esofagite. 2005.

[3] BARDINI, D. C. Avaliação da relação entre inteligência emocional e a prevalência de estresse ocupacional em profissionais atuantes em shoppings da Ilha de São Luís do Maranhão. 2020.

[4] BATISTA, C.A.F.S. A relação entre as emoções e as regiões 
abdominais (Pontos G). Dissertação de Mestrado em Medicina Tradicional Chinesa. INSTITUTO DE CIÊNCIAS BIOMÉDICAS ABEL SALAZAR. Porto, 2019.

[5] BOMBANA, J. A. (2006). Sintomas somáticos inexplicados clinicamente: um campo impreciso entre a psiquiatria e a clínica médica. J Brás Psiqu, 55(4): 308-312.

[6] BORRE, Y. E. et al. Microbiota and neurodevelopmental windows: implications for brain disorders. Trends in molecular medicine, v. 20, n. 9, p. 509-518, 2014.

[7] BRAVO, J. A. et al. Ingestion of Lactobacillus strain regulates emotional behavior and central GABA receptor expression in a mouse via the vagus nerve. Proceedings of the National Academy of Sciences, v. 108, n. 38, p. 16050-16055, 2011.

[8] DE ASSIS, C. L. et al. Percepções e práticas sobre psicossomática em profissionais de saúde de Cacoal e Nova Brasilândia/RO. Aletheia, n. 40, p. 74-86, 2013.

[9] DE JONGE, W. J. The gut's little brain in control of intestinal immunity. International Scholarly Research Notices, v. 2013, 2013.

[10] DEL'ARCO, A. P. W. T.; MAGALHÃES, P.; QUILICI, F. A. Sim Brasil study-women's gastrointestinal health: gastrointestinal symptoms and impact on the brazilian women quality of life. Arquivos de gastroenterologia, v. 54, p. 115-122, 2017.

[11] JIANG, H. et al. Composição alterada da microbiota fecal em pacientes com transtorno depressivo maior. Cérebro, comportamento e imunidade, v. 48, p. 186-194, 2015.

[12] KELLY, John R. et al. Brain-gut-microbiota axis: challenges for translation in psychiatry. Annals of Epidemiology, v. 26, n. 5, p. 366-372, 2016.

[13] LYTE, M. Probiotics function mechanistically as delivery vehicles for neuroactive compounds: microbial endocrinology in the design and use of probiotics. Bioessays, v. 33, n. 8 , p. 574-581, 2011.

[14] OZAN, Z. T.; TANIK, N.; INAN, L. E. Constipation is associated with tension type headache in women. Arquivos de neuro-psiquiatria, v. 77, p. 161-165, 2019.

[15] ROCHA JÚNIOR, J.R; et.al. O SISTEMA DIGESTÓRIO E AS EMOÇÕES.

[16] Cadernos de Graduação - Ciências Biológicas e da Saúde Fits | Maceió | v. 1 | n.2 | p. 97-110 | maio 2013.

[17] SILVA, B. E. et al. D et al. A influência do trabalho no nível de estresse em estudantes de psicologia. Revista Brasileira de Educação e Saúde, Paraíba, v. 6, n. 3, p. 23-25, 2016.

[18] WOYCIEKOSKI, Carla; HUTZ, Claudio Simon. Inteligência emocional: teoria, pesquisa, medida, aplicações e controvérsias. Psicologia: Reflexão e Crítica, v. 22, p. 1-11, 2009.

[19] YARANDI, S. S. et al. Modulatory effects of gut microbiota on the central nervous system: how gut could play a role in neuropsychiatric health and diseases. Journal of neurogastroenterology and motility, v. 22, n. 2, p. 201, 2016. 